Received: June 2, 2017

Revision received: March 13, 2018

\title{
An Empirical Study on the Effect of MBA Education in China: Comparison between Capital Market Performance and Social Responsibility Performance*
}

\author{
Huaping Zhang ${ }^{1}$ \\ North China University \\ of Water Resources and \\ Electric Power \\ Huiling $\mathrm{Liu}^{4}$ \\ Education Department of \\ Henan Province
}

\author{
Haichao Liu $^{2}$ \\ Peng $\mathrm{He}^{3}$ \\ North China University of \\ Water Resources and Electric \\ Power \\ North China University \\ of Water Resources and \\ Electric Power \\ Chao Yang ${ }^{5}$ \\ Education Department \\ of Henan Province
}

\begin{abstract}
From the perspectives of capital market performance and social responsibility, this paper empirically tests the effect of MBA education in China. The research shows that, on the one hand, the current problems of MBA education in China are mainly reflected in the following aspects: weak integration with the reality of Chinese enterprises, insufficient teachers, inadequate selection mechanism for students, less coordination between quality and quantity, and lower social recognition; on the other hand, the effect of China's MBA education is more reflected in the performance of social responsibility, and the company's social responsibility is better performed after the CEO received the MBA education compared to the Growth Enterprises Market (GEM) listed companies where the CEO didn't receive MBA education, but the company's performance in the capital market doesn't show any substantial difference. The research in this paper broadens the research scope of MBA education in China, and has certain reference value for understanding the actual effect of MBA education.
\end{abstract}

\section{Keywords}

MBA $\bullet$ Effect of MBA Education $\bullet$ Capital Market Performance $\bullet$ Social Responsibility

\footnotetext{
"This work was supported by Postgraduate Education Reform Project of Henan Province (No. 2017SJGLX003Y).

${ }^{1}$ Correspondence to: Huaping Zhang (PhD), North China University of Water Resources and Electric Power, Zhengzhou 450046, China. Email: zhanghuaping@ ncwu.edu.cn

${ }^{2}$ North China University of Water Resources and Electric Power, Zhengzhou 450046, China. Email: dahai9915@163.com ${ }^{3}$ North China University of Water Resources and Electric Power, Zhengzhou 450046, China. Email: 1052063029@qq.com ${ }^{4}$ Education Department of Henan Province, Zhengzhou 450018, China. Email: 87413231@qq.com ${ }^{5}$ Education Department of Henan Province, Zhengzhou 450018, Henan Province, China. Email: 553572687@qq.com
}

Citation: Zhang, H. P., Liu, H. C., He, P., Liu, H. L., \& Yang, C. (2018). An Empirical Study on the Effect of MBA Education in China: Comparison between Capital Market Performance and Social Responsibility Performance. Educational Sciences: Theory \& Practice, 18(5), 2582-2592. http://dx.doi.org/10.12738/estp.2018.5.001 
As an effective way to cultivate and bring up professional managers and create business elites and highlevel practical management talents, MBA education has been sought after by professional managers and business management personnel all over the world. Although from 1908 onwards, the United States Harvard University has created the MBA education, which was designed to cultivate "first-class moral enterprise management talents with a sense of responsibility", and established American Assembly of Collegiate School of Business in 1916, promoting the development, maturity and expansion of MBA education in the United States (Fu, 2005). However, since China experienced a special political system and economic development stage in the 1960s and 1970s, MBA education was formally introduced into China in the 1980s, along with the requirements of economic development for business talents after China's reform and opening up. In 1984, School of Management, Dalian University of Technology, China and School of Management, the State University of New York at Buffalo, US jointly opened MBA education in China for the first time, which is also the first MBA project in China, China's nine universities officially set MBA specialty since 1991, and MBA academic education was officially included in unified examination subjects by the Ministry of Education of the PRC in 1997, which means the formal start of MBA education in China (Zhou, 1998).

Because the MBA education not only focuses on imparting knowledge, but also pays more attention to the cultivation of practical ability and the comprehensive training in the decision-making and practical management skills, with the characteristics of high level, professionalism, practicality, comprehensiveness and internationalization, the MBA education caters to preferences of many Chinese professional managers or business management (Zhao, 2002). In 1991, China started the enrollment of students for the MBA education, and only 9 college recruited a hundred of students. By 2002, 65 colleges and universities opened the MBA education, with an accumulative enrollment of 47,000 students in total, and by 2011, more than 200 colleges and universities had the capacities for the MBA education, only colleges and universities in the Beijing area recruited more than 10,000 students a year. It can be seen that MBA education is developing very fast in China with wide space. Especially with the increase in the publicity of MBA education, many business executives, especially private executives, see MBA education as a good chance for a second education. But while MBA education has been popularized, the society has also produced some negative feedback on MBA education, arguing that MBA education is flashy without substance (Wang, 2015), which raises questions and discussions about the effect of MBA education in China. So, what kind of education effect that the MBA education has produced in China, and what effect that the CEOs who received MBA education will bring in the enterprise decision-making level are the key issues of this paper.

In the existing literature, there are more researches on the effect of CEO education, but there are few studies on the effect of CEOs who receive MBA education on Chinese enterprises. Zhang \& $\mathrm{Li}$ (2008) pointed out that the CEO who receives MBA education to help retain his or her position. Zhang, Li, \& Huang (2014) thought the management of MBA education will speed up the adjustment of capital structure, which indicates that MBA education shapes the risk preference of managers. However, the literature shows that China's MBA education has not been sufficiently effective and Yao, Li \& Kong (2014) studied that there is no significant difference in the performance of a company whose CEO has an MBA degree as compared to a company whose CEO doesn't have an MBA degree. Unlike the existing literature research, the study in this paper has the marginal contributions in two aspects: on the one hand, the study chooses MBA education in China as the research object, which is a realistic demand of education with rapid development of China's economy in recent years, as well as an ideal place for research other countries because of different education environment; on the other hand, this study focuses on the effect of capital market performance and corporate social responsibility as the effects of MBA education in China, which is also an issue that has not been paid attention to in the existing literature. 


\section{Institutional Background and Realistic Analysis}

\section{Reality of MBA education in China}

It has taken nearly 30 years that MBA becomes a formal academic education since it entered into China and then become popular in more colleges and universities in China. It has trained a lot of business administrative talents, but due to various reasons, there are a lot of problems on the development of MBA education in China, which affect the effects of China's MBA education.

First, MBA education lacks a better integration with the reality of Chinese enterprises. As China's MBA education is in the early stage of development, with references from the European and American MBA education system as well as curriculum arrangement, teaching materials and others. This is conducive to MBA education in China before and after the 21 st century, the rapid development of MBA education in China, and the introduction of new foreign management concepts to China. However, these foreign education ideas cannot continue to be integrated into China's local development over time. In particular, in the transformation period of China's social development, it's difficult to explain some current economic phenomena in China with traditional and western management theories (Zhao, 2002; Liu \& Yang, 2014), and even some cases of Chinese enterprises do not exist worldwide. Therefore, it is difficult for traditional MBA education system to meet the current China's economic development management concept, and also cannot achieve the effect that the CEOs of enterprises can make better use of the knowledge to manage and run the enterprises.

Second, MBA education lacks enough teachers. Based on theoretical knowledge, MBA education is to cultivate the comprehensive ability of combining theory with practice along with the practice experience of enterprise management. Therefore, teachers of MBA course should have not only theoretical knowledge, but also sufficient practical experience. However, in the current education system in China, most teachers in colleges and universities mostly graduated from normal schools or universities, or apply for a job in a university just after obtaining the doctor's degree, without practical experience from the enterprises and institutions, which makes them basically lack of practical experience and an understanding of the specific operation of the enterprises and institutions, and thus makes it impossible to combine the theory with practice well, which greatly reduces the quality of teaching, and fails to meet the requirements of the MBA education and achieve good education effect. This is a common issue of the current China's MBA education in all universities (You, 2007).

Third, MBA education lacks adequate selection mechanism for trainees. Although the current China's MBA education is subject to the unified examination proposed by the Ministry of Education of the People's Republic of China, and candidates are required of the working time to participate in the examination, but the MBA entrance examination is simpler than the entrance examinations of other master subjects, especially in the early years of the examination, and some provinces and cities implement regional MBA education examination, which are proposed by the local education department, which makes students enter the MBA learning phase with the uneven foundation. On the one hand, in recent years, MBA students in China tend to be younger, without enough practical experience, and it is difficult to cultivate these students to meet the management requirements of enterprises (Zhang, 2017). On the other hand, some MBA students don't want to learn knowledge, but to get a "diploma" or to build a better platform by making good use of opportunities in learning MBA, so that these students will not study hard and thus won't have a good effect of MBA education.

Fourth, MBA education lacks the coordination between quality and quantity. Because the MBA education lacks a sufficient student selection mechanism, the MBA education bears a heavy burden. On the one hand, at the beginning of the 21st century, since the MBA education can help to obtain higher economic benefits than ordinary master degree education, well-known Chinese universities have opened the MBA specialty one after another, and some universities have specially opened on-job MBA education for those business executives who cannot take a full-time study; on the other hand, more Chinese CEOs have also chosen to have a second study in the form of MBA education, which forms the "MBA hot" and promotes some CEOs who originally didn't intend to learn MBA are willing to "spend money" on it. But with the increase in the number of MBA education 
students, the quality of education has not risen. Some students who participate in MBA learning are not managers or professional managers of enterprises, so they do not have conditions for learning MBA. Therefore, MBA education in China appears to be very prosperous, but the educational effect has not been fully achieved.

Fifth, MBA education lacks sufficient social recognition. Due to the practical problems of MBA education, the MBA education in China has not completely reached the effect as scheduled. Although MBA education has a higher popularity, and has trained a lot of management talents for the development of Chinese enterprises, there is still a big gap from the original social expectations of MBA as scheduled. On the one hand, the talents trained by MBA education in China differ greatly from those of international MBA; on the other hand, the development of MBA education in China is too "extensive" (Zhang \& Tao, 2017), and even few colleges and universities only regard MBA education as the way to seek economic benefits, so the effect of MBA education has not been sufficiently recognized by the society.

\section{Effect of MBA education in China: capital market performance}

First of all, from the objectives of MBA education, MBA education is designed to cultivate the future management of the enterprises, and improve self-awareness and future expectations of CEOs who are involved in learning MBA. On the one hand, CEOs have gained stronger human capital stock through MBA learning (Gottesman \& Morey, 2006), and thus CEOs will have a better understanding of themselves, thinking that they are able to and more responsible for maintaining good performance of enterprises in the capital market; on the other hand, CEOs have higher positioning for their future development after the study of MBA, especially want to have a better prospect in the future professional manager market, thus these CEOs won't be blind to have short-sighted behaviors that aren't conducive to the development of the enterprises, but to establish a good managers' reputation, and obtain the popularity among shareholders and investors through stable performance of enterprises in the capital market.

Second, from the arrangement of MBA education courses, the courses will be set up for corporate investment and financing management and the operation in capital markets. For example, in China's best institutions of higher learning, MBA curriculum in Peking University includes Financial Markets and Financial Institutions, Securities Investment and others, that in Renmin University of China includes Capital Market, Securities Investment Analysis and others, while CEIBS, the top business school in China, includes Corporate Finance, Investment and others in MBA curriculum. Thus, the courses related to capital market investment and management has become an indispensable core module in MBA curriculum. Through the study of these theoretical courses, CEOs can better understand the characteristics of the capital market and the actual operation, and also can better deal with the performance of its corporate shares in the capital market.

Finally, from the results of MBA education, it will have a subtle influence on the CEOs who take part in the courses, thus affecting the enterprise decision-making of CEOs. Jin \& Myers (2006) believed that based on their own needs, CEOs will selectively disclose "good" information, and conceal the "bad" information, which will intensively break out once failing to be concealed, and lead to adverse reactions of businesses in the capital market. However, on the one hand, enterprise accounting information courses would be provided for CEOs in the learning process of MBA education, for example, the Tsinghua University opened Financial Report Analysis and Audit and CEIBS opened Financial Statement Analysis. From such courses, CEOs will have a better understanding of the enterprise financial accounting and recognize the importance of accounting information, and while the Renmin University of China also opened Commercial Law, which will make the CEO have a clearer understanding of the consequences of manipulating accounting information; on the other hand, through the learning of MBA, CEOs may also master more methods of running and managing enterprises and thus avoid to meet their own interest appeal through manipulating accounting information with more serious consequences and inhibit the desire and extent of CEOs for manipulating information.

Based on the above, the research hypothesis to be tested in this paper is put forward: 
H1: The effect of MBA education in China is reflected in the performance of enterprise capital market, that's, if CEOs participated in MBA education, the capital market of the enterprises performs better.

\section{Effect of MBA education in China: social responsibility performance}

First of all, from the objectives of MBA education, it aims at cultivating the enterprise management that meets the social need and thus it requires the CEOs to have certain social responsibility view.

In the current process of economic and social development in China, the previous "extensive" economic model has not been sustained, which requires the CEOs not only have economic awareness, but also meet the interests of all stakeholders in terms of social development, environmental development, and others, which is also advocated by MBA education. On the one hand, MBA education itself plays a role in fulfilling social responsibility. In the process of MBA education, MBA students will be organized to participate in social service activities, and the schools of MBA education itself will reflect their own social responsibility through code of ethics, guiding principle for running the school and others ( $\mathrm{Yu}, 2008$ ), which will produce impact on the students' social responsibility view. On the other hand, current Chinese MBA students also have the demand to learn social responsibility knowledge. According to the questionnaire conducted by Liu (2009), more than $90 \%$ of MBA students support the introduction of social responsibility courses in the course of their training.

Secondly, according to the arrangement of MBA education curriculum, the corresponding curriculum arrangement will be set up in terms of the corporate social responsibility. At present, many famous universities in the world have set social responsibility as MBA course (Lambrechts, Mulà, Ceulemans, Molderez \& Gaeremynck, 2013) and as of 2014, 26 colleges and universities in China have added social responsibility courses in MBA curriculum system (Memon \& Khattak, 2014). For example, Peking University particularly opened the course of Corporate Social Responsibility. The courses of corporate social responsibility help CEOs have a better understanding of the mode and ways of fulfilling the social responsibility.

Finally, from the results of MBA education, it will affect the CEOs' social responsibility decision. On the one hand, MBA education will increase the social capital of CEOs, which naturally allows enterprises to obtain material, information and emotional help, and thus increase the emphasis of CEOs on enterprises' intangible resources as well as CEOs' power and ability of accumulating intangible resources through social responsibility. On the other hand, CEOs will reduce their risk preferences through MBA education (Graham \& Harvey, 2002), which is also in line with the original intention and objectives of social responsibility.

Based on the above, the research hypothesis to be tested in this paper is put forward:

H2: The effect of MBA education in China is reflected in corporate social responsibility performance, that's, if the CEOs participated in MBA education, then their performance of corporate social responsibility will be better.

\section{Research Design}

\section{Sample data description}

With the GEM listed companies in China as samples, the study tests the effect of MBA education. The reasons for the GEM listed companies are selected as samples is that on the one hand the GEM companies are non-state-owned enterprises, so their CEOs have more obvious impact on their enterprises, and on the other hand, in the GEM companies, more CEOs received MBA education through a variety of ways. Therefore, excluding the samples of the IPO companies, the special processing companies, the companies whose CEOs don't have MBA education, and the corresponding data companies, the paper sets up 1,286 samples for testing the effect of MBA education on the capital market performance and 1,312 samples or testing the effect of MBA 
education on the social responsibility performance from 2010 to 2015 . The annual sample distribution is shown in Table 1.

Table 1

Sample Distribution

\begin{tabular}{cccccccc}
\hline \multicolumn{7}{l}{ Panel A: Capital market performance's sample yearly distribution } \\
\hline $\mathrm{N}$ & 2010 & 2011 & 2012 & 2013 & 2014 & 2015 & $2010-2015$ \\
$\%$ & 34 & 138 & 249 & 289 & 268 & 308 & 1286 \\
& $2.64 \%$ & $10.73 \%$ & $19.36 \%$ & $22.47 \%$ & $20.84 \%$ & $23.95 \%$ & $100.00 \%$ \\
\hline
\end{tabular}

Panel B: Corporate social responsibility's sample yearly distribution

\begin{tabular}{|c|c|c|c|c|c|c|c|}
\hline $\mathrm{N}$ & 34 & 132 & 243 & 286 & 283 & 334 & 1312 \\
\hline$\%$ & $2.59 \%$ & $10.06 \%$ & $18.52 \%$ & $21.80 \%$ & $21.57 \%$ & $25.46 \%$ & $100.00 \%$ \\
\hline
\end{tabular}

Note. Panel A shows the capital market performance's sample distribution by year. Panel B shows the corporate social responsibility's sample distribution by year.

\section{Empirical model design}

This paper respectively constructs an empirical model to test the effect of MBA education on capital market performance, and an empirical model to test that on social responsibility performance, that's,

$$
\begin{aligned}
& \operatorname{CMP}_{i, t}=\left(\begin{array}{l}
\alpha_{1} M B A+\alpha_{2} A w c y_{i, t}+\alpha_{3} S_{w c y_{i, t}}+\alpha_{4} \text { ROA }_{i, t}+\alpha_{5} \text { Debt }_{i, t}+\alpha_{6} \text { Size }_{i, t} \\
+\alpha_{7} H 10_{i, t}+\alpha_{8} A g e_{i, t}+\text { Year }+ \text { Industry }+C+\varepsilon
\end{array}\right) \\
& \text { CSR }_{i, t}=\left(\begin{array}{l}
\alpha_{1} M B A+\alpha_{2} \text { ROA }_{i, t}+\alpha_{3} \text { Debt }_{i, t}+\alpha_{4} \text { Size }_{i, t}+\alpha_{5} H 10_{i, t}+\alpha_{6} A g e_{i, t} \\
+ \text { Year }+ \text { Industry }+C+\varepsilon
\end{array}\right)
\end{aligned}
$$

\section{Variable definition}

(1) Explained variable: Capital Market Performance (CMP)

The risk of stock price collapse is used to measure the performance of corporate capital market, the lower the risk of stock price collapse is, the better the performance of the capital market is. According to Hutton, Marcus \& Tehranian (2009), Kim, Li \& Zhang (2011) and Kim, Li \& Li (2014), with NCSKEW and DUVOL to measure, the measurement method is as follows:

First, calculate the weekly return of the stock price in the capital market with the following formula:

$$
R_{i, t}=\alpha_{0}+\alpha_{1} R_{m, t-2}+\alpha_{2} R_{m, t-1}+\alpha_{3} R_{m, t}+\alpha_{4} R_{m, t+1}+\alpha_{5} R_{m, t+2}+\varepsilon_{i, t}
$$

Where, Ri,t is the cash dividend reinvestment return of I stock in the t week, and $R_{m, t}$ is the average return of all stocks in capital market in the t week through weighting current market value. According to Dimson (1979), the return in the capital market before and after the two periods is added. Revise based on the residual error item obtained from the Formula (1), that's,

$$
W_{i, t}=\ln \left(1+\varepsilon_{i, t}\right)
$$

Secondly, NCSKEW and DUVOL are respectively set up, that's,

$$
\begin{aligned}
& \operatorname{NCSKEW}_{i, t}=-\left[n(n-1)^{3 / 2} \sum W_{i, t}^{3}\right] /\left[(n-1)(n-2)\left(\sum W_{i, t}^{2}\right)^{3 / 2}\right] \\
& \operatorname{DUVOL}_{i, t}=\log \left\{\left[\left(n_{u}-1\right) \sum_{\text {down }} W_{i, t}^{2}\right] /\left[\left(n_{d}-1\right) \sum_{u p} W_{i, t}^{2}\right]\right\}
\end{aligned}
$$

In Formula (5) and Formula (6), $\mathrm{n}$ is the weeks of actual transactions of $i$ stock in the current year, nu is the weeks when the weekly return of $i$ stock is greater than the average value while nd is the weeks when the weekly 
return of i stock is less than the average value. The greater the NCSKEW and DUVOL value are, the smaller the risk of corporate stock price crash is, but the better the capital market performance is.

(2) Explained variable: Corporate Social Responsibility (CSR)

According to Yang \& Qiao (2013), the comprehensive degree of social responsibility performance is measured with different stakeholders' interests, that's,

$$
C S R=(G E+I R+W R+S R+C R)-N R
$$

Where, the first five items are to the positive social responsibility performed by the enterprises while the last item is the negative social responsibility with the specific definition of each variable:

$\mathrm{GR}=$ Government Responsibility $=($ taxes paid - tax return received $) /$ total assets; $\mathrm{IR}=$ Investor Responsibility $=$ Distribute dividends, profits or cash for payment of interest/ total assets; WR $=$ Worker Responsibility $=$ Payment to staff and cash for staff/operation revenue; SR = Supplier Responsibility = Cash to purchase goods and receive services / Operating cash outflow; $\mathrm{CR}=$ Contribution Responsibility = Charitable donation expenditure/total assets; NR $=$ Negative Responsibility $=$ Fine expenditure/total assets .

(3) Explanatory variable: MBA Education (MBA)

Taking the educational experience of corporate CEOs with or without MBA education, that's, if the CEOs' final education is MBA or once participated in MBA education, $\mathrm{MBA}=1$, otherwise, $\mathrm{MBA}=0$.

(4) Control variable

According to empirical models built in Formula (1) and (2), the corresponding control variables are explained as follows: Awcy is defined as the average weekly special yield of the sample enterprise every year; Swcy is defined as the standard deviation of weekly special yield of the sample enterprise every year; ROA is defined as the return of assets of the sample enterprise; Debt is defined as the debt-to-assets ratio of the sample enterprise; Size is defined as the total assets of the sample enterprise (Natural logarithm); Age is defined as the difference value of the current year with the previous year. Meanwhile, the paper further controls the effect of Year and Industry of the samples.

\section{Analysis of Empirical Test Results}

\section{Descriptive statistical analysis}

Table 2

Descriptive Statistics Panel A: Classification analysis of MBA education and capital market performance

\begin{tabular}{|c|c|c|c|c|c|c|c|c|}
\hline \multirow{2}{*}{ Variables } & \multicolumn{3}{|c|}{$\mathrm{MBA}=0$} & \multicolumn{3}{|c|}{$\mathrm{MBA}=1$} & \multirow{2}{*}{ T test } & \multirow{2}{*}{ Wilcoxon $Z$} \\
\hline & $\mathrm{N}$ & Mean & Median & $\mathrm{N}$ & Mean & Median & & \\
\hline NCSKEW & 1107 & -0.317 & -0.278 & 179 & -0.378 & -0.275 & 1.048 & 0.855 \\
\hline DUVOL & 1107 & -0.247 & -0.256 & 179 & -0.289 & -0.309 & 1.040 & 1.213 \\
\hline \multicolumn{9}{|c|}{ Panel B: Classification analysis of MBA education and corporate social responsibility } \\
\hline \multirow{2}{*}{ Variables } & \multicolumn{3}{|c|}{$\mathrm{MBA}=0$} & \multicolumn{3}{|c|}{$\mathrm{MBA}=1$} & \multirow{2}{*}{ T test } & \multirow{2}{*}{ Wilcoxon Z } \\
\hline & $\mathrm{N}$ & Mean & Median & $\mathrm{N}$ & Mean & Median & & \\
\hline CSR & 1124 & 0.784 & 0.813 & 188 & 0.813 & 0.834 & $2.782 * * *$ & $2.471 * * *$ \\
\hline
\end{tabular}

Note. Panel A shows the classification analysis on MBA education and capital market performance by dividing firmyears into difference groups. Panel B shows the classification analysis on MBA education and corporate social responsibility by dividing firm-years into difference groups. The p-values for the differences in means (medians) are based on t-tests (Wilcoxon tests). The Standard error reported in parentheses. *, **, and *** indicate statistical significance at the $10 \%, 5 \%$, and $1 \%$ levels, respectively. 


\section{Empirical test results}

Panel A in Table 2 compares the descriptive statistics in the samples of capital market performance. In these samples, about 13.9\% CEOs of China GEM listed companies received MBA education, and the higher proportion proves the popularity of MBA education in China. Compared to the group of MBA=0, NCSKEW and DUVOL are lower in the group of $\mathrm{MBA}=1$, which indicates that if $\mathrm{CEO}$ received MBA education, the risk of the stock price collapse of their enterprises is lower, that's, the better their capital market performance is, but they don't pass the corresponding T-test and Wilcoxon Z-test, the significance test of the conventional confidence level, which indicates that such differences in different enterprises are unstable.

Table 3

Empirical Test Results

\begin{tabular}{|c|c|c|c|}
\hline & NCSKEW & DUVOL & CSR \\
\hline MBA & $\begin{array}{l}-0.061 \\
(0.057)\end{array}$ & $\begin{array}{c}-0.042 \\
(0.041)\end{array}$ & $\begin{array}{c}0.021 * * * \\
(0.010)\end{array}$ \\
\hline Awcy & -12.465 & -13.240 & - \\
\hline Swcy & $-2.818^{*}$ & $-2.005^{*}$ & - \\
\hline ROA & 0.072 & -0.289 & $-0.345 * * *$ \\
\hline Debt & -0.081 & -0.034 & 0.207 *** \\
\hline Size & $0.110 * * *$ & $0.045^{*}$ & $-0.023 * * *$ \\
\hline $\mathrm{H} 10$ & -0.140 & 0.131 & $0.113^{* * * *}$ \\
\hline Age & $-0.056 * * *$ & $-0.037 * * *$ & $-0.007 * *$ \\
\hline Year & Yes & Yes & Yes \\
\hline Industry & Yes & Yes & Yes \\
\hline Constant & $-2.301 * * *$ & $-1.002 * * *$ & $1.215^{* * * *}$ \\
\hline No. of obs. & 1286 & 1286 & 1312 \\
\hline Adjusted $\mathrm{R}^{2}$ & 0.014 & 0.009 & 0.092 \\
\hline F-statistics & $3.337 * * *$ & $2.450 * * *$ & $19.984 * * *$ \\
\hline
\end{tabular}

Note. The Standard error reported in parentheses. * **, and *** indicate statistical significance at the $10 \%, 5 \%$, and $1 \%$ levels, respectively.

Panel B in Table 2 compares the descriptive statistics in the samples of social responsibility performance. In these samples, about $14.3 \%$ CEOs of China GEM listed companies received MBA education. Similarly, compared to the group of $\mathrm{MBA}=0$, variable $\mathrm{CSR}$ is higher in the group of $\mathrm{MBA}=1$, and can pass T-test and Wilcoxon Z-test of the conventional confidence level, which indicates that if CEOs of China GEM listed companies received MBA education, their companies pay more attention to the social responsibility performance.

Table 3 reports the regression test results of the effect of MBA education in China. From the impact of MBA education on the capital market performance, variable MBA and variable NCSKEW show a negative correlation, and variable MBA and variable DUVOL also showed a negative correlation, but they all failed to pass the significance test of the conventional confidence level, which shows that compared to the GEM listed companies of CEOs who didn't receive MBA education, the GEM listed companies of their CEOs who received MBA education have a better capital market performance, but the relationship between the two situations is uncertain. From the impact of MBA education on social responsibility, variable MBA and variable CSR showed a positive correlation, and passed the significance test of the conventional confidence level (1\%), which indicates that compared to the GEM listed companies of CEOs who didn't receive MBA education, the GEM listed companies of their CEOs who received MBA education have a better social responsibility performance. Therefore, when CEOs received MBA education, both their theoretical knowledge and practical experience have been improved, and CEOs recognize from MBA education the role of the social responsibility in enterprise development, realize to meet the interests of stakeholders through social responsibility performance, and thus contribute to better fulfill their social responsibilities, that's the good effect produced by MBA education in China. Therefore, we can see that the $\mathrm{H} 2$ in the previous paper has been verified accordingly. 
From test results of control variables in capital market performance samples, variables Swcy and Age and variables NCSKEW and DUVOL have a significantly negative correlation, variable Size and variables NCSKEW and DUVOL have a significantly positive correlation, while the relations between variables Awcy, ROA, Debt, H10 and variables NCSKEW and DUVOL don't pass the significance test of the conventional confidence level. From test results of control variables in social responsibility samples, variables ROA, Size, Age and variable CSR have a significantly negative correlation, variables Debt, H10 and variable CSR have a significantly positive correlation.

In order to further confirm the correctness of the foregoing conclusions, the robustness test is carried out. First of all, considering the delay of capital market performance and social responsibility performance, we choose the next-period value of the explained variable to measure the performance; second, considering that some Chinese universities incorporate the EMBA into the MBA education system, the CEOs who received EMBA education will be included into the research. There is no substantial difference between the results of the robustness test and the previous empirical results, which both indicate that the effect of MBA education in China is better reflected in the performance of social responsibility.

\section{Endogenous test results}

Although the affecting factors in the regression model are controlled in the above, there may still be endogenous problems of MBA education in the performance of capital markets or social responsibility. One possibility is that the CEO's personal characteristics decide whether he received or didn't receive MBA education, which thus may form a false relationship between the CEO's MBA education and capital market performance or social responsibility. So, in order to control endogenous problems, according to Fan, Wong \& Zhang (2007), and Li \& Srinivasan (2011), whether the CEO is CF and whether the CEO has COE are taken as tool variables, and the endogenous test was performed with two stages of regression.

Table 4

2SLS Estimation Test Results

\begin{tabular}{lccc}
\hline & NCSKEW & DUVOL & CSR \\
\hline \multirow{2}{*}{ MBA } & -0.068 & -0.046 & $0.021^{* *}$ \\
& $(0.058)$ & $(0.041)$ & $(0.010)$ \\
\hline Awcy & -14.151 & -14.341 & - \\
\hline Swcy & $-3.123^{* *}$ & $-2.205^{* *}$ & - \\
\hline ROA & 0.043 & -0.308 & $-0.345^{* * *}$ \\
\hline Debt & -0.088 & -0.039 & $0.207^{* * *}$ \\
\hline Size & $0.105^{* * *}$ & $0.042^{*}$ & $-0.023^{* * *}$ \\
\hline H10 & -0.073 & 0.174 & $0.113^{* * *}$ \\
\hline Age & $-0.054^{* * *}$ & $-0.036^{* * *}$ & $-0.007^{* * *}$ \\
\hline Year & Yes & Yes & Yes \\
\hline Industry & Yes & Yes & Yes \\
\hline Constant & $-2.156^{* * *}$ & $-0.907^{* * *}$ & $1.215^{* * *}$ \\
\hline No. of obs. & 1286 & 1286 & 1312 \\
\hline Adjusted R & 0.016 & 0.010 & 0.092 \\
\hline F-statistics & $3.264^{* * *}$ & $2.430^{* * *}$ & $19.983 * * *$ \\
\hline J statistic & 1.142 & 0.107 & 0.972 \\
\hline No & & 0.142
\end{tabular}

Note. The first-stage regression models are about MBA education and include two additional instrumental variables, which is CF and COE. The Standard error reported in parentheses. *, **, and *** indicate statistical significance at the $10 \%, 5 \%$, and $1 \%$ levels, respectively.

Table 4 reports the endogenous test results of the effect of MBA education in China. The negative correlation between variable MBA and variables NCSKEW and DUVOL still fail to pass the significance test of the conventional confidence level, while they have a significantly negative correlation, which show that after controlling endogenous problems, MBA education still promotes the performance of social responsibility, 
indicating that the effect of MBA education in China is better reflected in the performance of social responsibility.

\section{Conclusions and Implications}

Since the 1990s, MBA education in China has started from scratch and experienced from quantity to quality. At present, there are more than 200 colleges and universities offering MBA education in China, and the annual enrollment scale is more than 30 thousand. However, with the increase in the number of students in MBA education, the quality of MBA education has been questioned and MBA education launched in many colleges and universities didn't achieve the initial idea. Therefore, based on the perspectives of capital market performance and social responsibility, this paper empirically tests the effect of MBA education in China. The study has shown that, on the one hand, the current problems of MBA education in China are mainly characterized by the poor integration with the reality of Chinese enterprises, insufficient teachers, a lack of student selection mechanism, weak coordination between quality and quantity and lower social recognition; on the other hand, the effect of MBA education in China is more reflected in the performance of social responsibility, and compared to the GEM listed companies of their CEOs who didn't receive MBA education, the companies' social responsibility is better performed after their CEOs receive MBA education, but there are no substantial differences in the capital market performance. MBA education in China now entered a moratorium after the initial expansion, which partly because MBA education expanded rapidly in the much earlier period and thus many management personnel of enterprises and institutions received MBA education and partly because MBA education failed to be completely recognized by the society and the effect of MBA education failed to be completely reflected. From the empirical evidence of this paper, the effect of MBA education in China is only reflected in the performance of CSR, but not shown at the capital market level, which shows that even if the CEOs are involved in the MBA education, the good effect isn't reflected at all levels of the enterprises, and also shows that the current MBA education in China is largely divorced from the reality and lacks the sufficient combination of theories with practice.

Thus, for the current MBA education in China, on the one hand, we should develop MBA education with "Chinese characteristics" based on the actual situation of China's economic development. Taking into account the rapid development of China's economy in recent years and the practical problems faced by Chinese enterprises, we should combine MBA education with China's actual situation, including practical problems with Chinese characteristics, which enables the MBA students cultivated to solve the practical problems of China. On the other hand, we should put the focus of MBA education on practical problems. Currently, the MBA education in China obviously prefers the impartation of theoretical knowledge to the guidance of practical experience. MBA education should give more attention to practice to better reflect its effect.

\section{References}

Dimson, E. (1979). Risk measurement when shares are subject to infrequent trading. Journal of Financial Economics, 7(2), 197-226. http://dx.doi.org/10.1016/0304-405X(83)90039-9

Fan, J. P., Wong, T. J., \& Zhang, T. (2007). Politically connected CEOs, corporate governance, and Post-IPO performance of China's newly partially privatized firms. Journal of Financial Economics, 84(2), 330-357. https://dx.doi.org/10.1016/j.jfineco.2006.03.008

Fu, M. R. (2005). Research on the formation of American enterprise leaders in the 20th century. American Studies Quarterly, 19(1), 57-76. 
Gottesman, A. A., \& Morey, M. R. (2006). Manager education and mutual fund performance. Journal of Empirical Finance, 13(2), 145-182. http://dx.doi.org/10.1016/j.jempfin.2005.10.001

Graham, J., \& Harvey, C. (2002). How do CFOs make capital budgeting and capital structure decisions?. Journal of Applied Corporate Finance, 15(1), 8-23. http://dx.doi.org/10.2139/ssrn.795374

Hutton, A. P., Marcus, A. J., \& Tehranian, H. (2009). Opaque financial reports, R2, and crash risk. Journal of Financial Economics, 94(5), 67-86. http://dx.doi.org/10.1016/j.jfineco.2008.10.003

Jin, L., \& Myers, S. C (2006). R2 Around the World: New Theory and New Tests. Journal of Financial Economics, 79(2), 257-292.

Kim, J. B., Li, Y., \& Zhang, L. (2011). Corporate tax avoidance and stock price crash risk: Firm-level analysis. Journal of Financial Economics, 100(3), 639-662. http://dx.doi.org/10.1016/j.jfineco.2010.07.007

Kim, Y., Li, H., \& Li, S. (2014). Corporate social responsibility and stock price crash risk. Journal of Banking \& Finance, 43(1), 1-13. http://dx.doi.org/10.1016/j.jbankfin.2014.02.013

Lambrechts, W., Mulà, I., Ceulemans, K., Molderez, I., \& Gaeremynck, V. (2013). The integration of competences for sustainable development in higher education: An analysis of bachelor programs in management. Journal of Cleaner Production, 48(1), 65-73. http://dx.doi.org/10.1016/j.jclepro.2011.12.034

Li, F., \& Srinivasan, S. (2011). Corporate governance when founders are directors. Journal of Financial Economics, 102(2), 454-469. http://dx.doi.org/10.2139/ssrn.1663905

Li, Z. Y., \& Yang, X. N. (2014). The problems and countermeasures of MBA education model in China. Theory and Practice of Contemporary Education, 6(5), 76-78.

Li, G. (2009). The study of present situation and optimization countermeasures of corporate social responsibility education: an analysis of the questionnaire based on MBA students. China Higher Education Research, 15(11), 25-28.

Memon, Z. A., \& Khattak, M. A. O. (2014). The application of 'Corporate Social Responsibility' in business and management education. China Management Informationization, 17(15), 123-124.

Wang, Y. L. (2015). The problems analysis of the reform of MBA education in China. Continue Education Research, 32(6), 14-18.

Yang, Z. Z., \& Qiao, Y. H. (2013). The relationship among the industrial competition attribute, company characteristics, and social responsibility: Based on the empirical analysis of the listed company. Science Research Management, 34(3), 58-67.

Yao, M. A., Li, H. L., \& Kong, Y. (2014). CEOs' MBA educational background and corporate performance: an empirical analysis on MBA educational effects. Journal of Nanjing Audit University, 11(5), 63-74.

You, S. B. (2007). On the MBA education problems in China. Journal of Higher Education, 28(10), 80-82.

Yu, G. M. (2008). Study on the education of social responsibility for MBA programs. Shanghai Management Science, 30(5), 82-88.

Zhang, L. (2017). The problems and countermeasures of MBA teaching management in China. Western China Quality Education, 3(16), 124-125.

Zhang, L., \& Li, J. (2008). The impact of MBA education on top manager exit and promotion. Journal of Management Case Studies, 1(4), 7-14.

Zhang, L. L., Li, Q., \& Huang, G. L. (2014). Managers' MBA education and firms capital structure decisions: empirical analysis from listed companies of Shanghai and Shenzhen stock exchange. Research on Economics and Management, 35(2), 14-22.

Zhang, N., \& Tao, H. (2017). The reform of MBA education supply. Education Teaching Forum, 9(11), 78-79.

Zhao, S. M. (2002). MBA education and cultivation of China's professional managers. Journal of Higher Education, 23(3), 82-85.

Zhou, W. H. (1998). MBA education in China. Jiangsu Higher Education, 14(3), 64-66. 